\title{
A Bank Failure Prediction Model for Zimbabwe: A Corporate Governance Perspective
}

\author{
TinevimboSantu Chokuda ${ }^{1}$, Njabulo Nkomazana ${ }^{1}$, Wilford Mawanza ${ }^{2}$ \\ ${ }^{1}$ Midlands State University, Gweru, Zimbabwe \\ ${ }^{2}$ Lupane State University, Bulawayo, Zimbabwe \\ chokudatv@gmail.com, chokudatv@gmail.com,wilfordma@gmail.com
}

\begin{abstract}
The primary objective of this study was to come up with a bank failure prediction model for Zimbabwe. The research sample comprised five failed commercial banks that were operational in 2003 as well as five non-failed commercial banks that were operational during that same period. The model developed in this research was applied to each of these banks and a failure classification awarded. Out of a sample of ten banks, the model misclassified one bank as failed instead of non-failed and this signified a strong predictive power. Results revealed a distinct pattern of owner managed banks being predicted to fail while those banks run by professional managers, divorced from ownership, were getting high passes, a sign of stability. Some owner managed entities were predicted as non-failing and this was interpreted as emanating from a strong presence of institutional and other outside shareholders with a significant shareholding in the banks and thus eliminating shareholder concentration. The findings from the research showed that owner managers were more likely to commit corporate governance abuses than professional managers. It was concluded that corporate governance factors significantly contributed to the bank failures experienced in Zimbabwe between 2003 and 2004. As a result, banks need to focus more on corporate governance factors to avoid failures in the future.
\end{abstract}

Keywords: Bank failures, corporate governance, model, professional managers, Zimbabwe

\section{Introduction}

A review by the International Monetary Fund (IMF) revealed that 133 out of 181 member countries had experienced significant banking sector problems during the years 1980-1996 (Goodhart et al., 1998). The most notable failures being in Argentina, Chile and Uruguay (1979-1983), the Nordic banking crisis (19871994), Japan (1992), Mexico (1994), the Asian Financial Crisis (1998) and the Global Financial Crisis(2008). The increase in bank failures has rekindled interest in early warning systems. Bank regulators, in particular, are attracted to the prospects of models that assist them to predict banking distress in good time (Maimbo, 2000). In the last quarter of 2003 and the first quarter of 2004, a number of banking institutions in Zimbabwe faced serious challenges that ranged from chronic liquidity problems, deep rooted risk management deficiencies and poor corporate governance practices. By the end of 2004, ten (10) banking institutions had been placed under curatorship, two (2) were under liquidation and one discount house had been closed (Muranda, 2006).The fact that remains glaring and renders the Zimbabwean banking crisis significantly unique is that out of all the financial institutions operating at the time, only locally owned banks were affected.

The banking crisis that saw the collapse of these banks was triggered by the collapse of ENG Capital asset management and later developed into a fully-fledged systemic crisis only drawn apart from crises witnessed in other countries in that it seemed to affect only those banks with a significant domestic ownership. Other crises witnessed in different countries have been truly systemic in nature affecting banks randomly and indiscriminately with the only link between the collapsed institutions being shared structural weaknesses. The fact that all the collapsed institutions in Zimbabwe were locally owned cannot be treated as mere coincidence but points towards a far deep rooted problem. Coorey et al. (2005: 55) pointed out that, "It seems clear in retrospect, even if there was uncertainty at the time, that the difficulties faced by the banking sector in 2003-2004 were not systemic. The institutions affected in 2004 were all relatively small, collectively accounting for only about $12 \%$ of bank deposits and $16 \%$ of assets."The Reserve Bank of Zimbabwe (RBZ) responded by stepping up the regulatory regime and tightening entry requirements into the sector. Just as confidence was beginning to creep back into the sector another bank, Renaissance Merchant Bank was placed under curatorship at the beginning of June 2011after investigations revealed the collapse of corporate governance structures within the institution. The bank came under spotlight after several irregularities were found to be working against the interests of business. These included the collapse of corporate governance 
structures, gross abuse of depositors' funds, capitalisation through borrowed and depositors' funds, irregular shareholding structure, technical insolvency and lack of separation of ownership and management. The failure of yet another bank on the back of a seemingly tightened regulatory environment points towards the need for a lasting solution to the problem of continued bouts of instability in the sector.

The RBZ is currently using the CAMEL rating system as a way of determining bank soundness. A research carried out by Rojas-Sarez (1998) used bank level indicators based on the CAMEL model to evaluate bank failures in developing countries. She concluded that the CAMEL indicators were not good measures of bank strength in emerging countries and that what was required for them were simpler alternative measures that were more appropriate to the unsophisticated nature of developing countries. Furthermore, the inability of accounting data to reflect management quality, the collapse of corporate governance structures as a major contributing factor in bank failures and the failure to incorporate other important qualitative factors not easily quantifiable, may explain why bank failure prediction models have not had a strong predictive power in developing countries. There is need for coming up with measures that ensure early detection of likelihood of failure and subsequent prevention. In developed markets, a number of scholars have come up with models that address bank failure prediction. The thrust of this research is to come up with a model that is tailor made for the Zimbabwean context in view of the realities specific to the local financial services sector.

Statement of the Problem: It is worrying to note that bank failures continue to occur despite frameworks such as the Basel II that are designed to foster stability in financial systems globally. Diagnostic studies on the causes of these failures have been extensively carried out but the challenge as far as bank failures are concerned seems to lie more with the prevention aspect. The underlying factors behind bank failures appear to be the same for banks operating under similar conditions. Most academic work on bank failures can be traced to developed countries and has been targeted to address bank failures in developed markets. Most scholarly work done in this area is based on statistical and econometric models and these studies have made use of fundamentals that in some cases are largely appropriate to these specific markets. Financial markets in developing countries although largely governed by the same set of principles that govern financial markets elsewhere, have some factors peculiar to them with a significant bearing on their stability. The study thus sought to come up with an approach to bank failure prediction that is relevant to the Zimbabwean market in as far as it incorporates factors that have been seen to contribute heavily towards instability of the banking system in Zimbabwe.

The next section provides a brief review of literature related to the study and looks at the structure of bank failure prediction models developed by various scholars.

\section{Literature Review}

Predicting failures, due to whatever cause, reduces the length of time losses are incurred and the misallocation of resources (Meyer and Pifer, 1970). The Interest in predicting failures dates back to Secrist's classic study in 1934 where he examined banks that failed between the early 1920s and early 1930s. Given the importance of the subject of bank failure prediction at micro and macro levels, numerous models have been developed to predict bank failure. These models employ statistical techniques which include regression analysis, multivariate discriminant analysis, multivariate probit or logit analysis, arctangent regression analysis and factor logistic analysis among others. Although widely practiced, these models have been criticised for their problematic methodologies (Demyanyk and Hasan, 2009).Barr and Siems (1996) argued that for a bank failure prediction model to be useful to regulators, it must be understandable and easy to use. Bank failure prediction models have been built around financial ratios derived from accounting data and analysed using various statistical methods. Barr and Siems (1996) asserted that early warning models for banks began with Meyer and Pifer (1970) and since then various researchers have used multivariate techniques to explain past closures and predict future failures. Meyer and Pifer (1970) used stepwise regression program with binary dependent dummy variables to discriminate between bankrupt and solvent banks that faced similar local and national market conditions.

Multivariate techniques have been abundantly applied to bank failure prediction. Beaver (1966) is among the pioneers of bank failure prediction and he conducted a univariate analysis by examining the predictive ability 
of financial ratios with respect to bankruptcy. According to Ohlson (1980), research has found that discriminant analysis based models are theoretically flawed in a manner that reduces the likelihood that they could be generally effective at predicting failure. They went on to argue that, all these models suffer from the narrowness of any model that relies on quantitative data that is doubtful accuracy and the fact that quantitative data only represents a portion of the information an expert would use if asked to assess the likelihood of a company failing. They pointed out that none of these models effectively stipulates what occurs in practice and as such, they cannot be assumed to be sufficient as commercial risk assessment systems. Whalen (1991) examined a particular type of bank failure prediction model called a Cox proportional hazards model, which produces estimates of the probability that a bank with a given set of characteristics will survive longer than some specified length of time into the future. Using a relatively small set of publicly available explanatory variables, the model identifies both failed and healthy banks with a high degree of accuracy. A large proportion of banks that subsequently failed are flagged as potential failures in periods prior to their actual demise.

Thomson (1991) as cited by Jagtiani et al. (2003) models bank failures of all sizes based on Call Report data using a logit regression analysis. The probability that a bank will fail was modelled as a function of capital adequacy, asset quality, management quality, earnings performance, and the relative liquidity of the portfolio. These are CAMEL-motivated proxy variables. Thomson (1991) found that the majority of these factors were significantly related to the probability of failure as much as four years before a bank fails. Barr and Siems (1996) took on a different angle to bank failure prediction and presented a failure prediction model for detecting a bank's troubled status two years prior to insolvency using publicly available data a category of explanatory variable to capture the elusive yet crucial element of institutional success: management quality. The empirical results of the study confirmed that the quality of management is crucial to a bank's survival. Scores for surviving institutions are statistically higher than the scores for failed banks. These results are significant in that banks that survive can be statistically differentiated from banks that fail based on management quality scores generated by the DEA model. In the same vein, Cole and Gunther (1998) developed a model of bank failure, using a probit analysis to draw a comparison between the predictive power of off-site monitoring systems and the CAMEL ratings derived during onsite examinations. They found that the CAMEL ratings assigned to banks have a short life span not exceeding two quarters after which they lose their predictive power. They conclude that models built through use of accounting ratios still have to be relied upon as a complement to the on-site examinations.

In line with other statistical based prediction models, Gilbert, Meyer, and Vaughan (1999) compare univariate and multivariate models' ability to predict bank failures. They find that the "best" single variable varied from year to year, and that only multivariate models could provide consistently accurate predictions. One of the most significant variables in all their tests was the equity ratio. Maimbo (2000) departed from the other conventional approaches to bank failure prediction by carrying out a study on Zambian banks which sought to improve the diagnosis and prediction of bank failures by incorporating non-financial factors into the process of analysing bank performance. The objective of his research was to provide a simple, noneconometric, yet practical policy instrument for regulators and supervisors in small developing countries. The research evaluates the experience of the Bank of Zambia in analysing the performance of commercial banks in operation over the period December 1995 to December 1998. He concludes that the CAMEL-S model is a more flexible approach to the effective analysis and prediction of bank failures in Zambia. Parker, Peters and Turestsky (2002) investigated the association of various corporate governance attributes and financial characteristics with the survival likelihood of distressed firms. Results revealed suggest that firms that replaced their CEO with an outsider were more than twice as likely to experience bankruptcy. Furthermore, larger levels of block holder and insider ownership over the sample period were positively associated with the likelihood of firm survival.

In line with the study by Parker et al. (2002), Polsiri and Sookanapphibarn (2009) develop failure prediction models that incorporate both governance and financial variables and examine the impact of major corporate governance attributes, that is ownership and board structures on the likelihood of distress. They find that the presence of a controlling shareholder and the board involvement by controlling shareholders reduce the probability of corporate financial distress. Lee, Yeh and Liu (2003) integrate accounting, corporate governance, and macroeconomic variables to build up a binary logistic regression model for the prediction of 
financially distressed firms. Debt ratio and ROA are found to be significant explanatory accounting variables while the percentage of directors controlled by the largest shareholder (which measures negative entrenchment effect), management participation, and the percentage of shares pledged for loans by large shareholders are shown to have positive contribution to the probability of financial distress. Arena (2005) developed the first comparative empirical study of bank failures during the nineties between East Asia and Latin America using bank-level data. The results for East Asia and Latin America show that bank-level fundamentals significantly affect the likelihood of bank failure. According to Bongini, Claessens and Ferri (2001), one can identify the specific characteristics of distressed (or failed) institutions compared to nondistressed (or non-failed) institutions. These characteristics can be then used in developing systems to monitor the risk of distress of financial institutions in the future.

The use of corporate governance variables for formulation of failure prediction models is also supported by Yeh and Woidtke (2005) as cited by Li, Liang and Chu (2010) where they suggest that corporate governance factors, such as corporate board structure, concentrated ownership and shareholder concentration, should be taken into consideration when measuring the possibility of bankruptcy. In particular, these corporate governance variables are said to possess the characteristics of lead indicator prior to the event of distress.

The A score model developed by Argenti (1976) used qualitative data and suggested that business failure follows three predictable sequences:

- Defects (divided into management weaknesses and accounting deficiencies)

- Mistakes made (High gearing, overtrading and the big internal or external projects)

- Symptoms of failure (Financial Signs, creative accounting, non-financial signs and terminal signs).

According to ACCA (2008), each deficiency is given a mark (as shown in table 1) or given zero if the problem is not present. The total mark for defects is 45,45 for mistakes and 10 for symptoms of failure. Argenti's argument is that, if a company's management is weak, then it will inevitably make mistakes which may not become evident in the form of symptoms for a long period of time. Literature shows that a number of causes have been identified as being behind bank failures across the globe. In the past decade, however, the issue of lapses in corporate governance seems to have played a major role in triggering these failures. Of concern, however, is the fact that it is evident from literature that none of the failure prediction models that have been produced to date, place emphasis on corporate governance factors as significant variables in the construction of failure prediction models. According to Gramlich et al. (2010:199) 'models should be more precisely adjusted to a changing banking environment and should be able to integrate additional risks'. Hendricks, Kambhu and Mosser (2007) linked the new character of systemic risk to the increased complexity of financial products and the inter-linkages within the financial system and the fact that systemic crises are now more likely to be more market oriented than institution specific where disruptions in certain market fundamentals can trigger a crisis.

The CAMEL rating system has also been widely relied upon by regulators across the globe in the process of bank supervision and surveillance and has been used to complement failure prediction models. According to Cole and Gunther (1998:104), "CAMEL ratings incorporate a bank's financial condition, its compliance with laws and regulatory policies and the quality of its management and systems of internal control". They also point out that given the multiple dimensions of CAMEL ratings, their primary purpose is not to predict bank failures. The fact that CAMEL ratings quickly decay because of the quickly changing environment is also cited as an important aspect in evaluation of the CAMEL rating system. Cole and Gunther (1998) bring to the fore the important fact that the examination process and the CAMEL ratings it generates have numerous important uses, many of which are quite distinct from the relatively narrow task of identifying bank failures. This argument points towards the fact that the CAMEL rating model is a primary tool for every supervisory body and though it cannot be solely relied upon for bank failure prediction, models specifically targeted at this task can then be brought in as complementary measures. Rojas-Suarez (2001) however questions the use of the CAMEL variables to assess risk of financial institutions in developing countries. She argues that the system, designed for developed financial systems, performs poorly in signalling problems in emerging markets because of accounting deficiencies, supervisory framework and the illiquidity in the market for bank shares. 


\section{Methodology}

The model in this study is built around corporate governance variables as well as some risk management aspects. Choice of variables takes root in the aspects that have been paramount in bank failures experienced in Zimbabwe and also the level of importance placed on issues to do with risk management by the international regulatory frameworks, as well as the level of attention that has been given to capital adequacy by regulatory authorities locally. The risk management variables were included to increase robustness of the model in recognition of the fact that bank failure is much broader than corporate governance failures, although more emphasis is being placed on corporate governance variables in this instance. The model uses the " $\mathrm{A}$ " score model as a basis and drops some variables in the model for corporate governance variables while maintaining the scores as well as modifying some of the variables to align the corporate failure prediction model to a specific bank failure prediction model as shown in table 1 below.

Table 1: Variables for Inclusion in the Model Based On the A Score Model

\begin{tabular}{ll}
\hline A) DEFECTS (Original A Score model) & A) DEFECTS (Corp-Govbased model) \\
\hline i) Management weaknesses: & i) Lapses in Corporate Governance \\
Autocratic Chief Executive Officer (8) & Owner/Manager Chief Executive Officer \\
Failure to separate role of Chairman and Chief & Failure to separate role of Chairman and Chief \\
Executive Officer (4) & Executive Officer \\
Passive Board of Directors (2) & Passive Board of Directors \\
Lack of balance of skills in management team & Poor Board composition
\end{tabular}

financial, legal, marketing, etc (4)

Weak Finance Director (2)

Lack of depth in management (1)

Poor response to change (15).

ii) Accounting deficiencies:

No budgetary control (3)

No cash flow plans (3)

No costing system (3).

B) MISTAKES

High gearing - a company allows gearing to rise to such a level that one unfortunate event can have disastrous consequences (15)

Overtrading - this occurs when a company expands faster than its financing is capable of supporting. The capital base can become too small and unbalanced (15)

The big project - any external/internal project, the failure of which would bring the company down (15). C. SYMPTOMS

Financial signs - in the A score context, these appear only towards the end of the failure process, in the last two years (3).

Creative accounting - optimistic statements are made to the public and figures are altered (inventory valued higher, depreciation lower, etc). Because of this, the outsider may not recognise any change, and failure, when it arrives, is therefore very rapid (3).

Non-financial signs - various signs include frozen management salaries, delayed capital expenditure,

Absence of an autonomous Finance Director with absolute control on finances

Poor Board oversight

Disregard for governance procedures under the pressure of a change in operating environment.

ii) Risk Management Deficiencies

Absence of direct reporting of Risk Management department to the Chief Executive

Weak Internal controls

Non adherence to loan advances procedures for insider loan advances

B) MISTAKES

Significant mismatches between assets and liabilities

Inadequate capital not commensurate with the level of business activity

Overexpansion using Depositors' funds as opposed to equity

\section{SYMPTOMS}

Huge levels of Non performing insider loans, Negative equity position

Failure by External auditors to detect the precarious positions of these institutions even as they were facing imminent collapse. (In a way, one could say that these institutions were given a clean bill of health just before they failed pointing towards a possibility of creative accounting).

Failure to honour withdrawal of demand deposits 
falling market share, rising staff turnover (3).

Terminal signs - at the end of the failure process, the Regulatory authorities intervention

financial and non-financial signs become so obvious

that even the casual observer recognises them (1).

Failure classifications as per the model- Argenti (1976) interpreted the possible failure scores as follows:

Total Score
$0-10 \ldots \ldots \ldots \ldots \ldots \ldots \ldots \ldots \ldots \ldots \ldots \ldots \ldots \ldots$

The model adopted in this study is a general corporate failure prediction model and reconfiguring it to make it relevant to a banking scenario had its challenges. The incorporation of strictly corporate governance and the additional risk management variables presented further challenges by narrowing the scope within which to play around with the possible variables for inclusion in the model. The stance taken in this case to maintain the scores as per the original model, again required special attention to the 'replacement variables' as per the model derived out of the A score model to maintain alignment between the scores and the 'replacement variables' which brought in a certain measure of subjectivity which could negate model accuracy. In a bid to counter these limitations all the 'replacement variables' where possible, had to have a close relationship with the original variables which is why other significant corporate governance variables such as board size, ownership percentage of major shareholder, ownership percentage of institutional investors had to be left out of the model as they were too out of line with the original variables. The 'replacement variables' were also incorporated bearing in mind that they had to be in sync with the size of the score as per original model. A close look at the A score model reveals a positive relationship between the magnitude of the score and the level of the contribution to failure associated with the variable.

The research was based solely on secondary data sources due to the historical nature of the information required hence the reliance on documented information from the period under study. The study relied on information from publicly available financial statements as well as RBZ publications. Forensic audit reports as well as other RBZ publications revealed information on corporate governance violations by the collapsed banks while financial statements for the non-failed banks provided information on the corporate governance practices of these companies based on such aspects as the balance between non-executive directors and executive directors, the separation of the role of Chairman and Chief Executive Officer, shareholder concentration and the extent of non-performing related party loans.

\section{Results and Discussion}

The model was applied to each bank in the sample and each bank was awarded a failure classification based on the above interpretations. A summary of the results obtained is presented in table 2 below.

Table 2: Summary of Failure Classifications

\begin{tabular}{lll}
\hline Bank & Score & Failure Classification \\
\hline 1. Trust & 76 & Fail (Bank at risk) \\
2. Royal & 91 & Fail (Bank at risk) \\
3. Barbican & 88 & Fail (Bank at risk) \\
4. Time & 88 & Fail (Bank at risk) \\
5. Intermarket & 99 & Fail (Bank at risk) \\
6. ZB & 3 & High Pass \\
7. NMB & 15 & Pass \\
8. Kingdom & 14 & Pass \\
9. CBZ & 3 & High Pass \\
10. Metropolitan & 40 & Fail (Bank at risk) \\
\hline
\end{tabular}


Interpretation of Findings: The model correctly classified all the failed banks but misclassified one nonfailed bank as failed which shows a $90 \%$ predictive power. Both the failed and non-failed banks in this sample shared one common factor, and that is the fact that they were all operating under a challenging environment as evidenced by the macroeconomic fundamentals that prevailed during that period. While the failed banks were struggling with liquidity challenges, other banks such as NMB and CBZ managed to pay out dividends during that same period, signalling stability. The failure predictions are skewed towards the smaller banks (measured using total assets) and in this case the smaller banks could be perceived to be weaker than the bigger and more established banks which survived the crisis. This observation is supported by Gavin and Hausmann (1996) where they argued that macroeconomic factors that are often labelled as the major drivers of bank failures are only in essence catalysts that simply unearth weaknesses already existent in the banks that are destined to fail. The failures experienced in Zimbabwe are linked to the emergence of new entrants into the sector, mostly indigenous players (as shown in the research sample) as well as shifts in the regulatory environment ushered in by the then new RBZ governor in his bid to control the level of speculative activities that were encouraging divergence from core banking activities. Similarly, Honohan (1997) pointed out that regime shifts have been known to sometimes heighten the vulnerability of banking systems, whether by altering the incentives facing the banks or introducing new and inexperienced players, in this case the locally owned banks run by their founders.

The documented facts on these bank failures also reflect that the problems experienced in the banking sector were not entirely market wide factors given the pattern of failures. The major problems were non-performing loans, poor management, fraud, inadequate regulatory capital and weak risk management systems among other factors. From literature, banking crises have been shown to have their roots in poor bank operations characterised by a total disregard for best practice and that in developing countries, banks end up being siphoned of financial resources through related party lending and fraud (Oviedo, 2003).The bank failures in Zimbabwe can also be explained from a macroeconomic perspective where according to literature, financial crises can be a result of the interaction of shocks and vulnerability. Imprudent risk taking has an impact of increasing vulnerability unless that added risk is backed by an increase in the bank's capital base and this is supported by (Gavin and Hausmann, 1998). The banks that failed were taking on added risk through funding long term positions with demand deposits as well as extending huge amounts of related party loans that were unlikely to be repaid, without recapitalising their banks in line with these riskier positions.

The study revealed that, central to factors that led to the banking sector crisis, were corporate governance violations. The modern banking environment across the globe is increasingly becoming associated with bank failures whose roots can be traced to lapses in corporate governance. Literature suggests that manifestations of these lapses are different across markets. A variety of studies on bank failures in the developed world present manifestations in the form of largely imprudent risk taking spurred by incentive packages as well as poor regulatory mechanisms and limited board oversight in view of the increased complexity of the financial products and financial activities that are supposed to be under their watch. The developing world on the other hand is presented as having corporate governance problems in the form of a rudimentary approach to business, a serious lack of market discipline and a total disregard for regulations. Factors identified include boardroom squabbles arising from ownership structure and a lack of corporate discipline leading to banks becoming directionless and uncontrolled. Factors such as the extension of huge loans to directors which in most cases were not being serviced, use of depositor's funds for expansion purposes, related party lending, venturing in stock market activities and foreign exchange transactions, purchase of fixed assets using depositors' funds signified a serious lack of market discipline and a total disregard for regulations and this is in line with (Ogubunka, 2003).

The bank failures in Zimbabwe were initially misconstrued as being systemic in nature but the study revealed a distinct pattern in these failures. All the failed banks were owner managed, were owned by relatively new and presumably inexperienced players, had concentrated shareholding and had a high risk appetite which given adequate board oversight could perhaps have been kept in check. NMB and Kingdom banks in particular, though owner managed had institutional and outside investors with a significant stake in the bank. Old mutual had a significant stake in NMB while Meikles Africa limited and Old Mutual had sizable shareholdings in Kingdom Bank. The presence of these outsiders in a way helped diffuse power from a few individuals. While Ifeanye et al. (2011) conclude that diffused shareholding is characteristic of African 
markets and ownership is divorced from control leading to the promotion of management's interests at the expense of shareholders, the findings from this research show that the bulk of the new entrants in the sector have concentrated ownership which actually leads to corporate abuse and minority shareholder oppression.

The findings from the study suggest that banks in which the government has a significant stake are more stable than those that do not have significant government ownership. Both CBZ and ZB in which the government is a shareholder, were rated as 'high passes' by the model. This is in contradiction with Honohan (1997) who argues that, many banking crises in developing countries can be traced to pervasive government involvement where banks end up not operating as autonomous profit seeking entities but as a quasi fiscal mechanism. Becht et al. (2011) point out that, empirically it has been difficult to establish a link between bank failures and corporate governance partly because government rescues have masked the true extent of the banks' problems. The misclassification of Metropolitan bank as a bank likely to fail could probably be explained by the fact that the RBZ through its Troubled Bank Fund intervened and rescued the bank, when in fact it should have failed.

\section{Conclusion and Recommendations}

Corporate governance factors significantly explain the failure of Zimbabwean banks for the period 20032004. The fact that bank governance is unique means that corporate governance has a strong bearing on the overall stability of the bank. The findings from the research show that performance as measured by profit does not necessarily translate into bank stability. Bank specific factors are also more important than overall market conditions in ensuring bank stability. While other schools of thought argue that concentrated ownership increases the level of monitoring and control, the findings from this research suggest that, concentrated shareholding can also lead to corporate abuse since key decisions will be in the hands of a few. Board effectiveness in the light of the repeated occurrences of bank failures is thrown in doubt. Board members seem to be put in place as a compliance measure and have no real power in terms of steering the course of a bank. Boards are in most cases properly constituted comprising highly qualified professionals with vast experience in their areas of specialisation but who according to this research consistently displayed an inability to offer adequate oversight to the banks under their control. External auditors are not being as effective as they should be given their inability to unearth various corporate abuses within the banks that they were auditing. One could also conclude that this was largely because corporate abuses in the form of bad governance are not as conspicuous as abuses such as fraud and are thus more difficult to detect. This further shows the extent of the gravity of the problems of a corporate governance nature emanating from their elusive nature.

Bank failure prediction models need to be structured bearing in mind the relevant problems in today's operating environment. Focusing on the issue of minimum capital requirements in the Zimbabwean scenario while an important aspect, does not deal with the problem of bank failures decisively and is reactive rather than proactive. Corporate governance problems that characterised the bank failures of 2004 have again resurfaced years later (Renaissance, Interfin) and the problem is still corporate governance abuses. Having a buffer against losses is important but it is even more important to put in place measures that help avoid those losses at an early stage. Bank failure prediction models with a corporate governance bias should thus be adopted by regulators. A board of directors is meant to monitor the activities of management on behalf of shareholders but in the case of owner managed entities, there is a glaring conflict of interest in the choice of a board that is meant to be performing an oversight function on management. The central bank should regulate the shareholding structures in banks and put ceilings on the percentage holding that an individual can have to discourage concentrated shareholdings which have been seen to lead to shareholder dominance.

The CAMEL rating system should be used in conjunction with bank failure prediction models such as the one formulated in this study since they are more direct measures geared to specifically address the problems of bank failures and thus likely to yield better results in terms of identifying problem banks. Banking sector reforms should be implemented against a background of a complete understanding of the fundamental issues affecting banks and after a careful consideration of the likely effects of such reforms. Banking sector reforms should be preceded by rigorous feasibility studies that will attempt to forecast the likely impact of such reforms to avoid cases of well-meaning reforms having a negative impact on the very systems they are meant 
to improving. The elusive nature of corporate governance abuses calls for the implementation of periodic forensic audits of a proactive nature targeted at good corporate governance compliance over and above the general audits carried out by external auditors. The policy implication for the research is that regulators should take cognisance of the qualitative corporate governance factors in financial sector stability by paying more attention to corporate governance structures in banks and the government at large should also put in place legislative instruments which address white collar crime such as the abuse of depositors' funds. From the study, the failure predictions were skewed towards the smaller banks (measured using total assets) and in this case the smaller banks could be perceived to be weaker than the bigger and more established banks which survived the crisis. This implies that the regulator through their bank supervision and licensing division should have in place robust systems for vetting financial market players.

\section{References}

ACCA (2008). Business failure, Prediction and Prevention, Student Accountant

Arena, M. (2005). Bank failures and bank fundamentals: A comparative analysis of Latin America and East Asia during the nineties using bank level data, Bank of Canada working paper 2005-19

Argenti, J. (1976). Corporate collapse: The causes and symptoms, Mcgraw Hill

Barr, R. S. \& Siems, T. F. (1996). Bank failure prediction using DEA to measure management quality, Federal Reserve Bank of Dallas

Beaver, W. H. (1966). Financial ratios as predictors of failure. Journal of Accounting Research, 4, 71-111

Becht, M., Bolton, P. \& Roell, A. (2011). Why bank governance is different. Oxford review of economic policy, 27(3), 437-465

Bongini, P., Claessens, S. \&Ferri, G. (2001). The political economy of distress in East Asian financial institutions. Journal of financial services research, 19(1), 5-25

Choudhry, M. (2011). Effective bank corporate governance: Observations from the market crash recommendations for policy. Journal of Applied finance and banking, 1(1), 179-211

Cole, R. A. \& Gunther, J. W. (1998). Predicting bank failures: A comparison of on-and off-site monitoring systems. Journal of Financial Services Research, 13(2), 103-117.

Cole, R. A. \& Gunther, J. W. (1998). Predicting bank failures: A comparison of on-and off-site monitoring systems. Journal of Financial Services Research, 13(2), 103-117.

Coorey, S., Heytens, P., Muñoz, S., Mohapatra, S., Andrews, M., Mbabazi-Moyo, J. \& Ivaschenko, 0. (2005). Zimbabwe-Selected issues and statistical appendix: Washington, DC (No. 05/359). International Monetary Fund Country Report.

Demyanyk, Y. \& Hasan, I. (2009). Financial crises and bank failures: A review of prediction methods, Bank of Finland research papers 35

Gavin, M. \& Hausmann, R. (1996). Macroeconomic volatility and economic development, Inter-American development bank, Washington DC

Gavin, M. \& Hausmann, R. (1998). The roots of banking crises: the macroeconomic context, Inter-American development bank, Working paper 318

Gilbert, R. A., Meyer, A. P. \& Vaughan, M. D. (1999). The role of supervisory screens and econometric models in off-site surveillance. Federal Reserve Bank of St. Louis Review, (Nov), 31-56.

Goodhart, C., Hartman, P., Llewllyn, D., Rojas-Suárez, L. \& Weisbrod, S. (1998). Financial Regulation Why How and where now? Routledge, London.

Gramlich, D., Miller, G. L., Oet, M. V. \& Ong, S. T. (2010). Early warning systems for systemic banking risk: critical review and modelling implications. Banks and Bank Systems, 5(2).

Hendricks, D., Kambhu, J. \& Mosser, P. (2007). Systemic risk and the financial system. Federal Reserve Bank of New York Economic Policy Review, 13(2), 65-80.

Honohan, P. (1997). Banking system failures in developing and transition countries: Diagnosis and prediction, IS, Working paper No 39

Ifeanye, D. N., Olagunju, A. \& Adeyanju, O. D. (2011). Corporate governance and bank failure in Nigeria: Issues, Challenges and Opportunities. Research journal of finance and accounting, 2(2).

IMF country reports No 05/539. (2005). Zimbabwe selected issues and statistical appendix, pp55

Jagtiani, J., Kolari, J., Lemieux, C. \& Shin, H. (2003). Early warning models for bank supervision: Simpler could be better. Economic Perspectives-federal Reserve Bank of Chicago, 27(3), 49-59. 


\section{Journal of Economics and Behavioral Studies (ISSN: 2220-6140)}

Vol. 9, No. 1, pp. 207-216, February 2017

Lee, T., Yeh, L. \& Liu, R. (2003). Can corporate governance variables enhance the prediction power of accounting based financial distress prediction models, CEI working paper series, No 2003-14

Levine, R. (2003). The corporate governance of banks, Discussion paper No 3, http//www.gcgf.org

Lin, F., Liang, D. \& Chu, W. (2010). The role of non-financial features related to corporate governance in business crisis prediction. Journal of Marine Science and Technology, 18(4), 504-513

Maimbo, S. M. (2000).The prediction and diagnosis of bank failures in Zambia, Finance and development research programme working paper series, No 13

Meyer, P. A. \& Pifer, H. W. (1970). Prediction of bank failures. The journal of finance, 25(4), 853-868

Muranda, Z. (2006). Financial distress and corporate governance in Zimbabwean banks.

Ogubunka, U. M. (2003). Walking Ahead of Bank Distress. The Secrets of Safeguarding Your Money in Banks', Lagos: Rhema Enterprises, pp. 19-26

Ohlson, J. A. (1980). Financial ratios and the probabilistic prediction of bankruptcy. Journal of Accounting Research, 18(1), 109-31.

Oviedo, P. (2003). Macroeconomic Risk and Banking Crises in Emerging Markets Countries: Business Fluctuations with Financial Crashes. Mimeo.

Parker, S., Peters, G. F. \& Turetsky, H. F. (2002). Corporate governance and corporate failure: A survival analysis. Corporate governance, 2(2), 4-12.

Polsiri, P. \& Sookhanaphibarn, K. (2009). Corporate distress prediction models using governance and financial variables: Evidence from Thai Listed firms during the East Asian economic crisis. Journal of economics management, 5(2), 273-304

Rojas-Suarez, L. (1998). Rating banks in emerging markets: What credit rating agencies should learn from financial indicators? Institute for International economics.

Rojas-Suarez, L. (2001). Can international capital standards strengthen banks in emerging markets?

Thomson, J. B. (1991). Predicting bank failures in the 1980s. Economic Review-Federal Reserve Bank of Cleveland, 27(1), 9.

Whalen, G. (1991). A proportional hazards model of bank failure: An examination of its usefulness as an early warning tool; Economic Review, 1, 21-31. 